\title{
Effect of Supplementation of HQPM-1 Maize Grain on Production Performances in Cross Bred (Hampshire x Ghungroo) Grower Pigs
}

\author{
Keshab Barman ${ }^{1 *}$, Santanu Banik ${ }^{1}$, S. R. Pegu ${ }^{1}$, Sunil Kumar ${ }^{1}$, D. Konwar ${ }^{2}$, P. J. Das ${ }^{1}$, \\ J. I. Rahman ${ }^{1}$, A. K. Das ${ }^{1}$, Swaraj Rajkhowa ${ }^{1}$, S. L. Jat ${ }^{3}$ and Sujay Rakshit ${ }^{3}$ \\ ${ }^{1}$ ICAR-National Research Centre on Pig, Guwahati, Assam, India \\ ${ }^{2}$ FVSc \& AH, SKUAST-Jammu, RS Pura, Jammu, India \\ ${ }^{3}$ ICAR-Indian Institute of Maize Research, Ludhiana, India \\ *Corresponding author
}

\section{A B S T R A C T}

\begin{tabular}{|l|}
\hline Key w o r d s \\
HQPM-1 Maize \\
grain, Production \\
Performance, \\
Crossbred, Grower \\
Pigs
\end{tabular}

Keywords

HQPM-1 Maize grain, Production Performance, Crossbred, Grower

\section{Introduction}

Maize (Zea mays) grain is used as the major source of energy in pig diet. Maize constituting $50-60 \%$ of the total dietary composition and about $90-100 \%$ of total energy source in the pig diet. Therefore, maize grain plays an important role in pig feeding. There are different varieties of maize grain namely yellow maize, white maize, quality protein maize (QPM) etc. However, they are differing in nutrient composition
(Snow et al., 2004, Panda et al., 2010). QPM has a higher nutritional value for livestock (Kaul et al., 2019) and also reduce the requirement of feed by $3.4 \%$ in pig ((LopezPereira, 1992).Feeding QPM variety maize in livestock resulted in better performances as reported by different researchers (Omage et al., 2009, Panda et al., 2010, Panda et al., 2014; Barman et al., 2020). Normal maize protein is deficient in lysine and tryptophan and has less value for monogastric animals (Jia et al., 2013). However, QPM variety 
maize contains double the amount of lysine than normal maize (Panda et al., 2010). The International Maize and Wheat Improvement Centre (CIMMYT) have developed many varieties of QPM (Nuss and Tanumihardjo, 2011). Quality Protein Maize has a hard endosperm rich in lysine and tryptophan. In broiler chick, feeding of QPM maize enhance the growth and meat quality while in layers improved age at first egg laying, egg production, and egg quality parameters (Eshetie, 2017). In pigs, feeding of QPM improved the FCR, reduce the cost of production, increasing average daily gain as reported by different researchers (Mpofu et al., 2012; De-Quan and Shi-Huang, 1994) while no significant difference by replacing normal maize with QPM in pig as reported by Tiwari et al., (2013). HQPM-1 is single cross hybrid variety quality protein maize. Protein content varies from 10.7 to $10.95 \%$ as reported by other researchers (Carillo et al., 2004; Sangeeta and Grewal, 2018). Although lots of research was conducted to find out feeding value of QPM in livestock, there is scanty of literature on use of HQPM-1 feeding in pigs. Therefore, present study was conducted with the objective to see its effect on substitution of normal yellow maize by different level of HQPM-1 in crossbred (HS x $\mathrm{GH})$ grower pigs.

\section{Materials and Methods}

The experiment was conducted after approval from the institute animal ethics committee. Eighteen crossbred (HS x Ghungroo) grower pigs (weighing from $40.4 \pm 1.31$ to $40.69 \pm$ 3.73) were divided into three groups using randomized block design. Three different diets were used for feeding of the animals namely - $\mathrm{T}_{1}$ : standard grower ration without High Quality Protein Maize-1 (HQPM-1) grain, control diet, $\mathrm{T}_{2}$ : standard grower ration supplemented with 50\% HQPM-1grain, $\mathrm{T}_{3}$ : standard grower ration supplemented with
100\% HQPM-1 grain mixed with required salt and mineral mixtures similar to standard diet. The nutrient requirement of pigs was made as per BIS (1986). The pigs were fed on the experimental grower rations twice daily in the morning and evening. The experiment was conducted for a period of 45 days. Digestibility trial was conducted at the end of the experiment. The lysine and methionine are balanced in all the rations as per requirement. The ingredient composition of the ration is given in Table 1. The calculated (ARC, 1977) energy (ME, Kcal $/ \mathrm{kg}$ ) of experimental diet was 3284.8, 3371.5 and 3003.5 respectively in $\mathrm{T}_{1}, \mathrm{~T}_{2}$ and $\mathrm{T}_{3}$ group. Proximate composition was done as per AOAC (1990).

\section{Statistical analysis}

Feed intake, nutrient digestibility, feed conversion ratio (feed gain ratio), feed cost per $\mathrm{kg}$ gain, average daily weight gain was subjected to a one-way ANOVA with experimental diet $\left(\mathrm{T}_{1}, \mathrm{~T}_{2}\right.$ and $\left.\mathrm{T}_{3}\right)$ as fixed effect as per Snedecor and Cochran (1989). Differences were considered significant when $\mathrm{P}<0.05$.

\section{Results and Discussion}

The protein content $(\% \mathrm{DM})$ of the ration was $18.12 \pm 0.21,18.38 \pm 0.04$ and $18.44 \pm 0.11$ in $\mathrm{T}_{1}, \mathrm{~T}_{2}$ and $\mathrm{T}_{3}$ respectively and that of HQPM1and normal maize was $9.39 \pm 0.05$ and 8.53 \pm 0.22 respectively. Nitrogen free extract content $(\% \mathrm{DM})$ of the ration was $63.35 \pm$ $0.01,64.35 \pm 0.61$ and $63.90 \pm 0.09$ to in $\mathrm{T}_{1}$, $\mathrm{T}_{2}$ and $\mathrm{T}_{3}$ respectively and that of HQPM-1 and normal maize was $83.13 \pm 0.14$ and 84.33 \pm 0.24 respectively (Table 2). Similar nutritional composition of QPM maize grain was also reported other researchers (Panda et al., 2010; Sangeeta and Grewal, 2018). Similarly, Kaul et al., (2019) also reported that protein composition of hybrid variety of QPM ranged from 8.86 to $10.80 \%$. The crude 
protein, ether extracts and crude fiber content of HQPM-1 was found higher than normal maize. Similar result was also reported by Zhai et al., (2002).

The digestibility coefficient of DM ranged from $78.72 \pm 6.95$ to $89.07 \pm 5.22$ in $T_{3}$ to $T_{1}$ respectively and other was within this range of variation. Similarly, CP digestibility ranged from $75.76 \pm 4.93$ to $87.22 \pm 8.47$ in $T_{3}$ to $\mathrm{T}_{2}$ respectively and other was within this range of variation. The digestibility of $\mathrm{OM}, \mathrm{EE}, \mathrm{CF}$ and NFE was also followed the same patterns (Table 3). Nutrients digestibility was reduced (P>0.05) at $100 \%$ supplementation of HQPM- 1maize grain by replacing normal maize in comparison to control and $50 \%$ substitution of normal maize grain with HQPM-1 maize. Nutrients digestibility was found higher $(\mathrm{P}>0.05)$ at $50 \%$ substitution of normal grain by HQPM-1 maize in comparison to control and $100 \%$ substitution.

The reduction in digestibility of nutrients at $100 \%$ replacement of normal maize grain with HQPM-1 grain might be due to other dietary factors. The reduction of DM digestibility by feeding QPM maize grain in pigs in comparison to normal maize was also reported by Landin et al., (2014).

Table.1 Ingredient composition (wt/wt) of experimental ration

\begin{tabular}{|l|c|c|c|}
\hline Ingredients & $\mathbf{T}_{\mathbf{1}}$ & $\mathbf{T}_{\mathbf{2}}$ & $\mathbf{T}_{\mathbf{3}}$ \\
\hline Normal Maize (Yellow variety) & 60.0 & 30.0 & 0.0 \\
\hline HQPM-1 Maize & 0.0 & 30.0 & 60.0 \\
\hline Wheat bran & 12.0 & 12.0 & 12.0 \\
\hline Ground nut cake & 12.5 & 12.5 & 12.5 \\
\hline Soya bean meal & 14.0 & 14.0 & 14.0 \\
\hline Mineral mixture & 1.0 & 1.0 & 1.0 \\
\hline Salt & 0.5 & 0.5 & 0.5 \\
\hline Total & 100.0 & 100.0 & 100.0 \\
\hline Phytase, g & 40.0 & 40.0 & 40.0 \\
\hline Lysine, g & 100.0 & 100.0 & 100.0 \\
\hline
\end{tabular}

$\mathrm{T}_{1}=0 \%$ replacement of normal maize with HQPM-1, $\mathrm{T}_{2}=50 \%$ replacement of normal maize with HQPM-1, $\mathrm{T}_{3}=100 \%$ replacement of normal maize with HQPM-1

Table.2 Proximate composition of experimental diets

\begin{tabular}{|l|l|l|l|l|l|l|}
\hline Ration & OM \% & CP \% & CF\% & EE \% & Ash \% & NFE \% \\
\hline $\mathbf{T}_{\mathbf{1}}$ & $93.38 \pm 0.03$ & $18.12 \pm 0.21$ & $9.39 \pm 0.19$ & $2.48 \pm 0.01$ & $6.62 \pm 0.03$ & $63.35 \pm 0.01$ \\
\hline $\mathbf{T}_{\mathbf{2}}$ & $94.44 \pm 0.40$ & $18.38 \pm 0.04$ & $9.37 \pm 0.20$ & $2.35 \pm 0.05$ & $5.56 \pm 0.40$ & $64.35 \pm 0.61$ \\
\hline $\mathbf{T}_{\mathbf{3}}$ & $93.67 \pm 0.01$ & $18.44 \pm 0.11$ & $9.41 \pm 0.18$ & $1.92 \pm 0.21$ & $6.33 \pm 0.01$ & $63.90 \pm 0.09$ \\
\hline $\begin{array}{l}\text { HQPM-1 } \\
\text { Maize }\end{array}$ & $98.04 \pm 0.05$ & $9.39 \pm 0.20$ & $2.22 \pm 0.16$ & $3.31 \pm 0.17$ & $1.96 \pm 0.05$ & $83.13 \pm 0.14$ \\
\hline $\begin{array}{l}\text { Normal maize } \\
\text { yellow variety }\end{array}$ & $97.82 \pm 0.06$ & $8.53 \pm 0.22$ & $2.04 \pm 0.04$ & $2.92 \pm 0.12$ & $2.18 \pm 0.06$ & $84.33 \pm 0.24$ \\
\hline
\end{tabular}

$\mathrm{T}_{1}=0 \%$ replacement of normal maize with HQPM- $1, \mathrm{~T}_{2}=50 \%$ replacement of normal maize with HQPM-1, $\mathrm{T}_{3}=100 \%$ replacement of normal maize with HQPM-1 
Table.3 Effect of supplementation of QPM on nutrient digestibility in growing crossbred pigs

\begin{tabular}{|l|c|c|c|c|c|c|}
\hline Group & DM & OM & CP & EE & CF & NFE \\
\hline $\mathbf{T}_{\mathbf{1}}$ & $89.07 \pm 5.22$ & $89.00 \pm 5.56$ & $86.52 \pm 5.94$ & $83.46 \pm 8.10$ & $82.92 \pm 6.16$ & $92.16 \pm 4.43$ \\
\hline $\mathbf{T}_{\mathbf{2}}$ & $88.87 \pm 5.84$ & $89.61 \pm 5.49$ & $87.22 \pm 8.47$ & $89.56 \pm 6.32$ & $82.48 \pm 8.44$ & $92.46 \pm 3.45$ \\
\hline $\mathbf{T}_{\mathbf{3}}$ & $78.72 \pm 6.95$ & $78.64 \pm 5.64$ & $75.76 \pm 4.93$ & $79.93 \pm 6.58$ & $68.67 \pm 8.92$ & $84.04 \pm 6.17$ \\
\hline $\mathbf{P}$ & 0.477 & 0.407 & 0.481 & 0.66 & 0.452 & 0.47 \\
\hline Value & & & & & & \\
\hline
\end{tabular}

$\mathrm{T}_{1}=0 \%$ replacement of normal maize with HQPM- $1, \mathrm{~T}_{2}=50 \%$ replacement of normal maize with HQPM-1, $\mathrm{T}_{3}=100 \%$ replacement of normal maize with HQPM-1

Table.4 Effect of supplementation of QPM on nutrient utilization in growing crossbred pigs

\begin{tabular}{|l|c|c|c|c|}
\hline Parameters & $\mathbf{T}_{\mathbf{1}}$ & $\mathbf{T}_{\mathbf{2}}$ & $\mathbf{T}_{\mathbf{3}}$ & $\mathbf{P}$ value \\
\hline DM intake & $1180.0 \pm 37.4$ & $1180.0 \pm 20.0$ & $1190.0 \pm 10.0$ & 0.949 \\
\hline Initial weight & $40.4 \pm 1.31$ & $40.76 \pm 2.71$ & $40.69 \pm 3.73$ & 0.992 \\
\hline Final weight & $54.78 \pm 1.19$ & $55.24 \pm 2.65$ & $54.66 \pm 3.71$ & 0.992 \\
\hline growth & $319.8 \pm 33.5$ & $321.8 \pm 9.7$ & $310.4 \pm 7.1$ & 0.917 \\
\hline FCR & $3.81 \pm 0.28$ & $3.69 \pm 0.16$ & $3.84 \pm 0.1$ & 0.917 \\
\hline Feed cost/kg gain & $102.3 \pm 7.5$ & $98.0 \pm 4.2$ & $100.9 \pm 1.9$ & 0.832 \\
\hline
\end{tabular}

$\mathrm{T}_{1}=0 \%$ replacement of normal maize with HQPM- $1, \mathrm{~T}_{2}=50 \%$ replacement of normal maize with HQPM$1, \mathrm{~T}_{3}=100 \%$ replacement of normal maize with HQPM-1

The dry matter intake $(\mathrm{g} / \mathrm{d})$ ranged from $1180.0 \pm 37.4$ in $\mathrm{T}_{1}$ to $1190.0 \pm 10.1$ in $\mathrm{T}_{3}$ group. The DM intake was found similar $(\mathrm{P}>0.05)$ across all treatment groups. In contrast to the present findings, Mpofu et al., (2012) found reduced feed intake in weaner pigs by inclusion of QPM maize grain. The average gain in weight $(\mathrm{g} / \mathrm{d})$ was ranged from $310.4 \pm 7.1$ in $T_{3}$ to $321.8 \pm 9.7$ in $T_{2}$ group. The gain in weight was found higher $(\mathrm{P}>0.05)$ at $50 \%$ inclusion of HQPM-1 in the diet in comparison to other two groups. Improvement in growth in pigs when supplemented with QPM by replacing normal maize was also reported by other researchers (Mbuya et al., 2011; Yongfeng and Jay-Lin, 2016). The FCR was ranged from $3.69 \pm 0.16$ in $\mathrm{T}_{2}$ to $3.81 \pm 0.28$ in $\mathrm{T}_{1}$ group (Table 4). Dry matter intake and growth was found similar across all groups. However, FCR was improved $(\mathrm{P}>0.05)$ in $\mathrm{T}_{2}$ group supplemented with $50 \%$ HQPM-1 maize grain in comparison to $0 \%$ and $100 \%$ HQPM-1 maize grain supplemented groups. Improvement in FCR and growth upon supplementation of QPM in pig was also reported other researchers (Gao, 2002; Mpofu et al., 2012).

The feed cost per $\mathrm{kg}$ gain (Rs $/ \mathrm{kg}$ gain) ranged from $98.0 \pm 4.2$ in $\mathrm{T}_{2}$ to $102.3 \pm 7.5$ in $\mathrm{T}_{1}$ groups and other was within this ranged. Feed cost per kg gain was reduced $(\mathrm{P}<0.05)$ by Rs. 4.3 and 1.4 in $\mathrm{T}_{2}$ and $\mathrm{T}_{3}$ groups in comparison to $\mathrm{T}_{1}$ group. Supplementation of QPM maize grains in pigs has reduced the cost of production as also reported by Mpofu et al., (2012). Similarly, Omage et al., (2009) also reported that feeding QPM to rabbits reduced cost of production.

From this study, it is concluded that supplementation of HQPM-1 maize grain at $50 \%$ level in crossbred grower pigs result in better performances in comparison to 0 and $100 \%$ replacement of normal maize with HQPM-1 maize grain. 


\section{Acknowledgements}

The authors are grateful to the Director, ICAR-IIMR, Ludhiana for providing financial assistance under NEH grant of the Institute and also grateful to the Director, ICAR-NRC on Pig, Guwahati, Assam, India for providing facility for conduction of the trial.

\section{References}

AOAC.1990. Official Methods of Analysis, $15^{\text {th }}$ Edition, (Eds. Kenneth Helrich) Association of Official Analytical Chemists, Inc., Suite 400, 2200 Wilson Boulevard, Arlington, Virginia 22201, USA.

ARC. 1977.Agricultural Research Council, 1134 Park street, Hatfield, Pretoria, P.O. Box 8783, Pretoria, 0001, South Africa.

Barman, K., Banik, S., Pegu, S.R., Kumar, S., Rahman, J.I., Das, A.K., Rajkhowa, S., Jat, S.L. and Rakshit, S. 2020. Effect of supplementation of QPM maize fodder on production performance in Large White Yorkshire grower pigs. EC Vety. Sci.(in Presss).

BIS. 1986. BIS Specifications for Compounded Feeds for Pigs (IS: 7472 - 1986), Bureau of Indian Standard, 1986, India.

Carillo JM, Dorado RG, Rodriguez EOC, Tiznado JAG, Moreno CR. 2004. Nixtamalized flour from quality protein maize (Zea mays L.). Optimization of alkaline processing. Plant Foods for Human Nutrition. 59:35-44.

De-Quan, S. and Shi-Huang, Z. 1994. Maize production and QPM breeding program in China. International Symposium on QPM. December 1-3 SeteLagoas, MG Brazil pp 238-239.

Eshetie T. 2017. Review of quality protein maize as food and feed: in alleviating protein deficiency in developing countries. American J.Food Nutr., 5(3): 99-105.DOI:10.12691/ajfn-5-3-4.

Gao, J. 2002. Nutritional evaluation and utilization of quality protein maize Zhong Dan 9409 in pig feed. MSc Thesis, Chinese Academy of Agricultural Sciences, Beijing 100081, P. R. China. Chinese Academy of Agricultural Sciences. (M.Sc. thesis).

Jia, M., Wu, H., Clay, K., Jung, R., Larkins, B. and Gibbon B.2013. Identification and characterization of lysine-rich proteins and starch biosynthesis genes in the opaque 2 mutant by transcriptional and proteomic analysis. BMC Plant Biol., 13: 60.

Kaul, J., Jain, K. and Olakh, D. 2019. An Overview on Role of Yellow Maize in Food, Feed and Nutrition Security. Int.J.Curr.Microbiol.App.Sci., $\quad 8(2)$ : 3037-3048. https://doi.org/ 10.20546/ ijcmas.2019.802.356.

Landín, G.M., de Souz, T.C.R. and Rodríguez, E.R. 2014. Metabolizable energy, nitrogen balance, and ileal digestibility of amino acids in quality protein maize for pigs. J. Anim.Sci. Biotechnol., 5:26. doi: 10.1186/20491891-5-26.

Lopez-Pereira, M. A., 1992. The economics of quality protein maize as an animal feed: Case studies of Brazil and EI Salvador, CIMMYT, Mexico, DF.

Mbuya, K., Nkongolo, K., Kalonji-Mb, A., 2011. Nutritional analysis of quality protein maize varieties selected for agronomic characteristics in a breeding program. Intl. J. Pl. Breed. \& Genet. 5: 317-327 doi 10.3923/ijpbg.2011.317.327.

Mpofu, I.D.T., Sibanda, S., Shonihwa, A. and, Pixley 2012. The Nutritional Value of Quality Protein Maize for Weaner Pigs. J. Pet Environ. Biotechnol. 3:129. doi:10.4172/2157-7463.1000129.

Nuss, E.T. and Tanumihardjo, S.A. 2011. 
Quality protein maize for Africa: closing the protein inadequacy gap invulnerable populations. Adv. Nutr., 2: $217-224$.

Omage, J.J., Agubosi, O.C.P., Bawa, G.S. andOnimisi, P.A. 2009. Evaluation of the nutritive value of quality protein maize on the growth performance and carcass characteristics of weaner rabbits. Pakistan J.Nutr.8: 106-111.

Panda, A. K., Raju, M. V. L. Rama Rao, N., S. V. and Lavanya, G. 2010. Replacement of Normal Maize with Quality Protein Maize on Performance, Immune Response and Carcass Characteristics of Broiler Chickens. Asian-Aust. J. Anim. Sci. 23(12): 1626 $-1631$.

Panda, A.K., Zaidi, P.H., Rama Rao, S.V., Raju, M.V.L.N. 2014. Efficacy of quality protein maize in meeting energy and essential amino acid requirements in broiler chicken production. J Appl Anim Res. 42:133139.

Sangeeta and Grewal, R.B. 2018. Physical and chemical properties of corn varieties (HQPM-1 and HQPM-7). Int. J. Chem.Stud., 6(3): 3380-3382.

Snedecor, G.W. and Cochran, W.G. 1989.
Statistical Methods, $8^{\text {th }}$ Edition, Iowa University press, Ames, Iowa (USA).

Snow JL, Stein HH, Ku PK, Trottier NL. 2004. Amino acid digestibility and nitrogen utilization of high oil, high lysine, and waxy maize fed to growing pigs. Anim. Feed Sci. Technol., 113: 113- 126.

Tiwari, M.R., Chapagain, P.B., Shah, M.K. and Shrestha, Y.K. 2013. Evaluation of Quality Protein Maize (QPM) and Normal Mazie for Growth Performance of Crossbred Piglets in Wester Hills of (Nepal). Global J.Sci. Frontier Res. Agric. Vet, 13(6).

Yongfeng, A., and Jay-Lin, J., 2016. Macronutrients in corn and human nutrition. Compre. Reviews. Food Sci. Food safety, 15: 581-598. doi.org/10.1111/1541-4337.12192.

Zhai, S.W. 2002. Nutritional evaluation and utilization of quality protein maize Zhong Dan 9409 in laying hen feed. MSc Thesis, Shaanxi 712100, P. R. China, Northwestern Agricultural and Forestry University of Science and Technology, Shaanxi 712100, P. R. China. (M.Sc. thesis).

\section{How to cite this article:}

Keshab Barman, Santanu Banik, S. R. Pegu, Sunil Kumar, D. Konwar, P. J. Das, J. I. Rahman, A. K. Das, Swaraj Rajkhowa, S. L. Jat and Sujay Rakshit. 2020. Effect of Supplementation of HQPM-1 Maize Grain on Production Performances in Cross Bred (Hampshire x Ghungroo) Grower Pigs. Int.J.Curr.Microbiol.App.Sci. 9(08): 1762-1767. doi: https://doi.org/10.20546/ijcmas.2020.908.203 